Available online at GSC Online Press Directory

GSC Biological and Pharmaceutical Sciences

e-ISSN: 2581-3250, CODEN (USA): GBPSC2

Journal homepage: https://www.gsconlinepress.com/journals/gscbps

(REVIEW ARTICLE)

CrossMark $\leftarrow$ click for updates

\title{
The prospects of the use of insects as an alternative source of proteins and medicine for human
}

\author{
Adewuyi H. Abdulsalam 1, ${ }^{*}$, Arogbokun 0. Adejoke ${ }^{1}$, Jaiyeola T. Olubukola ${ }^{1}$, Ajiboye Jamal ${ }^{2}$, Bawala A. \\ Enogela ${ }^{1}$, and Berinyuy B. Eustace ${ }^{3}$ \\ ${ }^{1}$ Department of Biochemistry, Federal University of Technology, Minna Nigeria. \\ 2 Department of Animal Biology, Federal University of Technology, Minna Nigeria. \\ ${ }^{3}$ Faculty of medicine and biomedical sciences, University of Yaounde, Yaounde, Cameroon.
}

Publication history: Received on 12 April, 2019; revised on 28 September 2019; accepted on 30 September 2019

Article DOI: https://doi.org/10.30574/gscbps.2019.9.1.0129

\begin{abstract}
Insects are highly efficient source of protein for humans, either through a direct consumption or as food supplements for many nations have already been using it. The high protein content is an indication that the insects can be of value in man and animal ration and can eventually replace higher animal protein usually absent in the diet of rural dwellers in developing countries. The protein content differs by species of insects, but generally is of a good quality and high digestibility. This review sheds a limelight on the prospect use of insects as an alternative source of human protein and medicine. However, the West refuses entomophagy as disgusting, businesses, industry, governments, and research will be positively impacted once the eating of insects is widely accepted. Replacing vertebrate livestockderived foods and food ingredients with those derived from insects will also substantially improve the health of the earth's natural environment. In this respect, the review explain the latest information on nutritional contents and supplements, insect as animal feed, efficiency, health value and insects as the future prospect of human meat.
\end{abstract}

Keywords: Insect; Entomophagy; Proteins; Medicine; Human

\section{Introduction}

The utilization of insects as a sustainable and secure source of animal-based food for the human diet has continued to increase in popularity in recent years [1]. Insect feeding is traced to human evolutionary history [2]. By all accounts, which include archeological evidence as well as analysis of fossilized feces, humankind has evolved as an entomophagous species [3]. Over the time, however, cultures and religions developed, where eating insects or any form of animal protein is discouraged to prevent animal sacrifice [4] or because of disgust [5]. Throughout the world, a large portion of the human population consumes insects as a regular part of their diet. Thousands of edible species have been identified [6]. However, in regions of the world where Western cultures dominate, such as North America and Europe, and in developing countries heavily influenced by Western culture, mass media have negatively influenced the public's perception of insects by creating or reinforcing fears and phobias [3]. However, the advantage benefits of farming and utilizing insects as a primary dietary component, which replace foods and food ingredients made from vertebrate livestock, are gaining increased global attention. Thus, the emergence of insect is at all levels, in every sector of food science and medicine.

\footnotetext{
${ }^{*}$ Corresponding author

E-mail address: hasselbatch@gmail.com
} 


\section{Nutritional and human health value of insects}

The United Nations (UN) has placed heavy emphasis on alleviating hunger and malnutrition in children. And to eradicate extreme poverty and hunger and the fourth is to "reduce child mortality rates" [7]. The possible health benefits of insect consumption might just change your mind. Eating bugs could combat obesity. Insects are considered highly nutritional; the majority of them are rich in protein, healthy fats, iron, and calcium, and low in carbohydrates. In fact, the authors of the FAO report claim that insects are just as - if not more - nutritious than commonly consumed meats, such as beef.

The low fat content of insects has led some researchers - such as those involved in the FAO report - to suggest that entomophagy may be an effective way to combat obesity and its related diseases [3]. The benefits of entomophagy do not stop at weight loss; the UN say eating insects could help combat malnutrition, which is widespread in developing countries.

According to UNICEF, worldwide, almost half of all deaths among children under the age of 5 years are a result of malnutrition, with most of these deaths occurring in Asia and Africa. A lack of nutrition, whether due to not having enough to eat or the inability to digest the food that is eaten, can increase the risk of life-threatening disease [3].

Malnutrition in the first 1,000 days of life can lead to stunted growth, which can impair cognitive function. As well as being a very good source of healthy fats and protein, insects are everywhere, meaning they are a very accessible, cheap source of food - a fact that could really benefit low- and middle- income countries where malnutrition is common [8].

\section{Pharmacological activities of Insect and their Products}

Previous reviews [9-11], have documented the pharmacological activities of insect and their products. House flies (Musca domestica) larvae, Honeybees (Apis melliflera) and their products have been reported for significant antiparasitic activities including antimalarial and antitrypanosoma in in vivo studies [12-13]. Evaluation of Biochemical parameters has been proven to be a reliable method of assessing the deleterious effect of substance or outcome of a particular treatment on the integrity of organs that would have been compromised in stress or disease condition [1418]. Insect and its products have been proven to provide significant protective effect to organs particularly the liver and kidney during toxicant/stress or parasite induced damages in animals [19]. Propolis from honey bee has been reported for haematopoietic properties [20] and hepatocurative effect against CCL 4 toxicant [21].

\section{Nutritional content of insects compared with other high-protein foods}

Insects are particularly high in protein, at levels comparable to those of beef and milk [22]. House crickets, for example, contain approximately $205 \mathrm{~g}$ of protein per kilogram of cricket, while ground beef contains about $256 \mathrm{~g}$ per kilogram and whole powdered milk contains about $265 \mathrm{~g}$ per kilogram [22]. Some estimate that the digestibility of flour made from insects is as high as 91\% [23]. Protein from various sources, in dried form, is most frequently found in village markets of the developing world. Insects are very high in crude protein, with many species ranging above $60 \%$ by dry weight [24]. Some insect proteins are equivalent to soy protein, whereas others are superior as a source of amino acids at all levels of intake. Whole insects as a source of protein are of somewhat lower quality than vertebrate animal products because of the indigestibility of chitin. Removal of chitin increases the quality of insect protein to a level comparable to that of products from vertebrate animals. In general, insect protein tends to be low in amino acids such as methionine and cysteine, but it is high in lysine and threonine, one or both of which may be deficient in the wheat-, rice-, cassava-, and maize-based diets that are prevalent in the developing world [25].

Insects are also particularly rich in fat [22] and can supply a high caloric contribution for energy-dense foods. In the reviews by Bukkens, all insect species were found to be a "significant source of the essential fatty acids linoleic and linolenic acid" $[23,26]$. Some insects can also provide a higher caloric contribution to the diet than soy, maize, or beef [2]. Cholesterol levels in insects vary from low to approximately the levels found in other animals, depending on the species and diet. Insect fatty acids are similar to those of poultry and fish in their degree of unsaturation, with some groups being rather higher in linoleic and/or linolenic acids, which are the essential fatty acids [25]. In addition to protein, fat, and caloric content, many insects are particularly high in a number of vitamins, minerals, and other valuable nutrients. For example, many species are significantly higher in thiamin and riboflavin than whole-meal bread and hen's eggs [23]. The retinol and betacarotene content of many insect species is also high, with levels in 
some species as high as $356 \mathrm{mg} / \mathrm{kg}$ and $1800 \mathrm{mg} / \mathrm{kg}$, respectively [22]. However, currently very limited data are available for vitamin analyses of insects, and more studies are needed.

Table 1 Nutritional contents of some insects

\begin{tabular}{|c|c|c|c|c|c|}
\hline $\begin{array}{l}\text { Inspector food } \\
\text { item }\end{array}$ & Protein g/kg & Fat (g/kg) & calories (g/kg) & $\begin{array}{l}\text { Thiamin } \\
\text { Calories }\end{array}$ & riboflavin(kcal/kg) \\
\hline Black soldier fly & 175 & 140 & 1994 & 7.7 & 16.2 \\
\hline Housefly & 197 & 19 & 918 & 11.3 & 77.2 \\
\hline House- cricket & 205 & 68 & 1402 & 0.4 & 34.1 \\
\hline Super-worm & 197 & 177 & 2423 & 0.6 & 7.5 \\
\hline Mealworm & 187 & 134 & 2056 & 2.4 & 8.1 \\
\hline Giant- mealworm & 184 & 168 & 2252 & 1.2 & 16.1 \\
\hline Waxy worm & 141 & 249 & 2747 & 2.3 & 7.3 \\
\hline Silkworm & 93 & 14 & 674 & 3.3 & 9.4 \\
\hline Beef & 256 & 187 & 2776 & 0.5 & 1.8 \\
\hline Milk powder & 265 & 268 & 4982 & 2.6 & 14.8 \\
\hline
\end{tabular}

\section{Insects as a sustainable source of human food}

As the human population grows, it is ever more important to sustain rather than increase our levels of consuming and harvesting materials from the earth and its ecosphere. The world adds about 70 million people each year. The United Nations expects the population to grow to more than 9 billion people by 2050, adding approximately twice the current population of China [29]. Insects have great potential in contributing to global food security. Insects are increasingly considered for another benefit they offer - as a source of animal protein. With an average of $80 \mathrm{~kg}$ of meat per year, Dutch consumers eat an amount that is between the Americans (120 kg/ year) and Chinese (50 kg/year). [29]. The use of insects as a major human food source presents two important technological challenges: how to turn insects into safe, healthy, and tasty food products; How to cheaply, efficiently, and sustainably produce enough insects to meet market demand. Many also advocate the wild harvesting of insects as human food as a solution to hunger and global food security. While this may be a reasonable short-term solution in a number of isolated situations in certain localities, we feel strongly that for full realization of the potential benefits derived from utilization of insects as a safe, reliable, and sustainable alternative to vertebrate livestock, the ultimate goal must be the efficient farming and/or mass production of insects. Insects have numerous attributes that make them highly attractive, yet underexplored, sources of highly nutritious and sustainable food [30-31].

\subsection{Efficiency}

Insects can be produced more sustainably and with a much smaller ecological footprint than most vertebrate livestock such as cattle and swine. They are very efficient at biotransformation of a wide variety of organic matter into edible insect biomass [32]. For example, cows consume $8 \mathrm{~g}$ of food mass per gram of weight gained, whereas insects can require less than $2 \mathrm{~g}$ [2]. This is partly due to insects being poikilothermic ("cold blooded"), thus using less energy for body warmth since they utilize their environment for body temperature regulation [33]. House crickets (Achetadomesticus L.) have an "efficiency of conversion of ingested food (ECI) that is twice that of pigs and chickens, 4 times that of sheep and 6 times that of steer" [2]. This efficiency can also lead to less usage of pesticides on animal feed, thus providing additional environmental, health, and economic incentives.

In addition to their highly efficient feed conversion ratios and diet variability, insect fecundity, rapid growth rates, and short life cycles add to the greater efficiency with which they can be produced as a human food ingredient compared with vertebrate livestock [2]. Insects tend to reproduce quickly, are highly adaptable, have large numbers of progeny per individual (high fecundity), and have a large biomass. For example, house crickets can lay 1200-1500 eggs in a 34 week period [2]. 


\subsection{Biodiversity}

There are over 1 million insect species described and 4-30 million species estimated to exist on earth, living in every niche inhabited by humans and beyond. Out of these, over 1000 are edible. The mean insect diversity are estimated to be 5.5 million [25]. Beetles (Coleoptera) make up 40\% of described insect species, but some entomologists suggest that flies (Diptera) and Hymenoptera (wasps, bees and ants) could be as diverse or more so. Five orders of insects stand out in their levels of species richness: Hymenoptera, Diptera, Coleoptera, Lepidoptera, and Hemiptera. A recent study estimated the number of beetle species at 0.9-2.1 million with a mean of 1.5 million [25]. While biodiversity loss is a global problem, conserving habitat for species of insects is uncommon and generally of low priority, although there are exceptions.

\section{Mass-produced insects for human food}

\subsection{Orthoptera}

Orthoptera is the fifth most consumed insect order worldwide. Acrididae represent the highest frequency of human consumption (171 species), followed by Gryllidae (34 species) and Tettigoniidae (30 species) [34].

\subsection{Diptera}

Flies (order Diptera) are the fourth most consumed insect order by humans, with 16 families and 39 total edible examples documented in the literature [34]. They are probably the insects with the largest reproductive insects for Human Consumption capacity, shortest life cycles, and rapid growth rates and that are able to eat the widest variety of organic material as feed input for mass production of insect biomass. These and other features make them some of the most attractive insects for applications to increase world food security from a production perspective.

Fly larvae are known to contain other antimicrobial compounds, some of which might improve the shelf life of food ingredients made from them [7]. Additionally, several aspects of this fly give it the potential for highly efficient and sustainable production. Black soldier fly larvae can develop on almost any kind of nontoxic organic matter, including a wide array of agricultural byproducts [35].

\subsection{Coleoptera}

At the species level, the insects most commonly consumed by humans worldwide are the Coleoptera, with 661 documented species being consumed among 26 families [34]. Interest in using mealworms and super worms as human food has increased recently in the United States. They are featured as edible insects in many entomology outreach programs and are being purchased by various businesses and incorporated into hard candies as well as baked goods such as cakes, cookies, and cupcakes. Mealworms and super worms can be easily rear on multiple types of vegetables and grains by the general public in a small space and are often used as an educational teaching tool in $\mathrm{K}$ 12 classrooms to demonstrate complete metamorphosis. Mealworms and super worms may be considered more acceptable for human consumption due to their minimal appendages.

\subsection{Lepidoptera}

Worldwide, more families of Lepidoptera (36) are consumed by humans than any other insect. The most commonly consumed families are Saturniidae (109 species), Hepialidae (47 species), and Sphingidae (36 species). Their frequency of human consumption is highest in the Neotropicaland Palearctic biogeographical realms [34] In the United States, a commonly consumed Lepidopteran insect by humans is the waxworm (G. mellonellaL.). They are mass reared for the animal feed industry as well as for fish bait. Their nutrient content is well established [28].

Due to their holometabolous life cycle and lack of noticeable appendages during the larval stage, they are also a great candidate for roasting, grinding into flour, and incorporating into various food products. They are very high in fat, which makes them an appealing food supplement in resource-limited areas where people are malnourished and underfed.

\section{Potential products and by-products from mass-produced feed insects}

Various insect-based food ingredients, can be incorporated into numerous consumer items such as "meat" substitutes, protein-fortified bars and nutritional powders, as well as numerous types of snack foods [7]. 
Replacing vertebrate animal meat (muscle and other tissue) in our diet with protein-rich meat-like products derived from insects is well achieved. The internal protein of insects behaves very similar to other proteins and meats when cooked, with similar textures, flavors, and odors. Even most of the vertebrate livestock-derived products such as sausages, hotdogs, ground beef chicken and nuggets often contain substantial amounts of fillers and other nonmeat ingredients as well as seasoning to improve their palatability. Thus, with a little research and development for applying existing meat and meat substitute production methods to mass-produced or mass-farmed insects as starting raw material, many products currently made from vertebrate animals could be made quite easily from insects [37].

In the short term, protein supplements for athletes and others wishing to increase their protein consumption also present a simple and ripe opportunity for incorporation of insect-derived protein. Much of the protein in these products comes from peanuts or soy. As earlier mention animal-derived protein is superior to protein from plants, so the best protein supplements also must include some animal protein [36].

\subsection{Unconscious consumption of insect}

People around the world eat insects unknowingly, as it is almost impossible to avoid contamination by insects or their parts in food and many states had worked out lists with prescribed permissible levels of insect contamination in food [38]. Therefore, it is obvious that also the people who dislike insects have consumed insects or parts of them before, which contaminated food during food production or processing. The availability of freely living edible insects is unpredictable, both in time and in location [39]. Therefore, such ethnic groups must leverage cur-rent food supplies, as they lack the more sophisticated methods of preservation than drying in the sun or smoking over afire. This readily available source of food is also used be- cause of the sheer necessity [40].

\subsection{Risks and toxicity of insect}

It has been reported that consuming grasshoppers and locusts whole, without removing legs, may lead to intestinal constipation, caused by the large spines on the tibia. Often the only way to relieve the patient in such situation is surgical removal of the locust legs. Autopsies of monkeys, that died during locust invasion also proved, that the consumption of locusts was fatal for the same reason [27]

Epidemics of an acute ataxic syndrome occur annually in the rainy season in parts of south-western Nigeria, characterized by intention tremors, ataxia and varying levels of impaired consciousness, following a carbohydrate meal [28]. Enzyme reaction can decrease cellular free thiamin concentration, carbohydrate metabolism or energy production can be impaired. Thiaminase activity in Japanese silkworms (B. mori) is less than one-third that of Anaphe spp. The results indicate the need for thorough heat treatment for detoxification of the African silkworm, making the worm a safe source of high quality protein [40]. An-other problem is the pesticide applications against locusts and grasshoppers, which can cause problems because of their toxic residues [31].

\section{Conclusion}

Insects play an important role in the diet of many nations. Because of the nutritional value is mainly determined by a high content of protein, essential fatty acids, vitamins, minerals and other bioactive substances. However, the West refuses entomophagy as disgusting, if we shall consider using insects as a food source of protein for humans in future, we must respect the issue of nature preserving, especially in the tribal societies and the overproduction of food in developed society. Insects provide critical basic tools for studying a great many aspects of biology. Human and animal protein products derived from insect cell lines are marketed for a number of purposes, including drug screening and clinical trials.

\section{Compliance with ethical standards}

\section{Acknowledgments}

The authors would like to acknowledge the scientific advice of Dr. Adeniyi A.K. of Animal Biology, Federal University of Technology, Minna, Nigeria

\section{Disclosure of conflict of interest}

The authors declared that no conflict of interest exist 


\section{References}

[1] Bodenheimer FS. (1951). Insects as Human Food, A Chapter of the Ecology of Man. The Hague, The Netherlands Bondari, K, Sheppard, D.C, 1981. Soldier fly larvae as feed in commercial fish production. Aquaculture, 24, 103109.

[2] Gahukar RT. (2011). Entomophagy and human food security. Int. J. Trop. Insect Sci. 31, 129-144.

[3] FAO U. (2008). In, Durst, Patrick B, Johnson, Dennis V, Leslie, Robin N, Shono, Kenichi (Eds.), Forest Insects as Food, Humans Bite Back, Regional Office for Asia and the Pacific, Chiang Mai, Thailand.

[4] Ozimek L, Sauer WC, Kozikowski V, Ryan JK, Jorgensen H and Jelen P. (1985). Nutritive value of protein extracted from honey bees. J.Food Sci, 50, 1327-1329.

[5] Borkovcova M, Bednarova M, Fiser V, Ocknecht P and Kuchynehmyzemzpestrena. (2009). 1st ed, Lynx, Brno, Czech Republic. 136, 37-4.

[6] Bukkens GF. (2005). Insects in the human diet, Nutritional aspects, 2005, In M.G. Paoletti, ed. Ecological implications of minilive-stock, 545-577.

[7] Dossey AT. (2013). Why insects should be in your diet. Scientist. 27, 22-23.

[8] Adamolekun B, McCandless DW and Butterworth RF. (1999). Epidemic of seasonal ataxia in nigeria following ingestion of the African silkworm Anaphevenata, Role of thiamine deficiency Metab. Brain Dis, 7 (12), $251-258$.

[9] Bashir L, Shittu OK, Sani S, Busari MB and Adeniyi KA. (2015).African Natural Products with Potential Antitrypanosoma Properties, A Review. International Journal of Biochemistry Research \& Review. 7(2), 45-79.

[10] Lawal B, Shittu OK, Kabiru AY, Jigam AA, Umar MB, Berinyuy EB and Alozieuwa BU. (2015). Potential antimalarials from African natural products, A review. J. Intercult Ethnopharmacology, 4(4), 318-343.

[11] Lawal B, Shittu O.K, Inje OF, Berinyuy EB and Muhammed, H. (2017). African Natural Products with Potential Antioxidants and Hepatoprotectives Properties, A Review, Clinical Phytoscience, 2, 23, 1-66.

[12] Shittu OK, Lawal B and Oluyomi OI. (2014). Effects of Methanol Extract of Musca domestica Larvae on Antioxidants Enzymes in T. Brucei Infected Rats. Nigerian Journal of Biochemistry and Molecular Biology, 29(2), 1-10.

[13] Shittu OK, Elekwechi U, Musa BB and Lawal B. (2015). Antitrypanosomal Activities and Effect of Ethyl Acetate Extract of Honey Bee (ApisMellifera) on Haematological Parameters of TrypanosomaBruceibrucei Infected Rats. Journal of Advances in Biology \& Biotechonology, 3(1), 29-35.

[14] Yusuf AA, Lawal B, Yusuf MA, Omonije YO, Adejoke AA, Raji FH and Wenawo DL.(2018).Free Radical Scavenging, Antimicrobial Activities and Effect of Sub-Acute Exposure to Nigerian Xylopia Aethiopica Seed Extract On Liver and Kidney Functional Indices of Albino Rat. Iranian journal of toxicology, 12 (3), 51-58.

[15] Yusuf AA, Lawal B, Abubakar AN, Berinyuy EB, Omonije YO, Umar SI, Shebe MN and Alhaji YM. (2018). In-vitro antioxidants, antimicrobial and toxicological evaluation of Nigerian Zingiber officinale. Clinical Phytoscience, 4 , 12, 1-8.

[16] Lawal B, Shittu OK, Oibiokpa IF, Mohammed H, Umar SI and Haruna GM. (2016). Antimicrobial evaluation, acute and sub-acute toxicity studies of Allium sativum, Journal of Acute Disease, 5(4), 296-301.

[17] Bashir L Shittu OK, Busari MB, Sani S and Aisha MI- (2015).Safety Evaluation of Giant African land Snails (Archachatina marginata) Haemolymph on Hematological and Biochemical Parameters of Albino Rats. Journal of Advances in medical and Pharmaceutical Sciences, 3(3), 122-130.

[18] Shittu OK, Lawal B, Blessing Uchenna AB, Haruna GM, Abubakar AN and Berinyuy EB. (2015). Alteration in Biochemical Indices Following Chronic Administration of Methanolic Extract of Nigeria Bee Propolis in Wister Rats. Asian Pacific journal of tropical disease. 5(8), 654-657.

[19] Shittu OK, Lawal B, Adeniyi AK, Kilani LT and Saka RB. (2017). Effect of Methanol extract of Musca domestica larva on some Enzymes and Haematological parameters in Trypanosoma brucei brucei - infected rats. Nigerian Journal of Basic and Applied Science, 25(2), 66-74.

[20] Lawal B, Shittu OK, Abubakar AN, Haruna GM, Sani S and Ossai PC. (2015). Haematopoetic Effect of Methanol Extract of Nigerian Honey Bee (Apis mellifera) Propolis in Mice. Journal of Coastal Life Medicine, 3(8), 648-651. 
[21] Shittu OK, Lawal B, Haruna GM, Berinyuy EB, Yusuf AA and Ibrahim AM. (2015). Hepato-Curative Effects of Methanol Extract From Nigeria Bee Propolis in Carbon Tetrachloride (CCL4) Intoxicated Rat. European Journal of Biotechnology and Bioscience, 3(6), 12-16.

[22] Bukkens SGF. (2005). Insects in the human diet, nutritional aspects. In, Paoletti, M.G. (Ed.), Eco-logical Implications of Minilivestock, Potential of Insects, Rodents, Frogs, and Snails, Science Publishers, Enfield, NH, 545-577.

[23] Bukkens SGF. (1997). The nutritional value of edible insects. Ecology of. Food and Nutrition, 36, 287-319.

[24] Christensen DL, Orech FO, Mungai MN, Larsen T, Friis H and Aagaard-Hansen J. (2006).Entomophagy among the Luo of Kenya, a potential mineral source? Int. J. Food Sci. Nutriton. 57, 198-203.

[25] DeFoliart GR. (1995). Edible insects as minilivestock. Biodiversity Conserv. 4, 306-321.

[26] Paoletti MG and Dreon AL. (2005). Minilivestock Environment, Sustainability, and Local Knowledge Disappearance, In M.G. Paoletti, ed. Ecological implications of minilivestock, enfield NH, Science Pub, USA, 648.

[27] Finke MD. (2005). Nutrient composition of bee brood and its potential as human food.Ecol. Food Nutr, 44, 257270.

[28] Finke MD. (2012). Complete nutrient content of four species of feeder insects. Zoo Biol.

[29] Dzamba J. (2010).Third Millennium Farming. Is it Time for Another Farming Revolution? Archi-tecture, Landscape and Design, Toronto, CA.

[30] Crabbe N. (2012). Local expert gets funding to develop insect-based food for starving children. Gainesville Sun, 1B-6A 649.

[31] Dossey AT. (2010). Insects and their chemical weaponry, new potential for drug discovery.

[32] Nakagaki BJ and Defoliart GR. (1991). Comparison of diets for mass-rearing Achetadomesticus (Orthoptera, Gryllidae) as a novelty food, and comparison of food conversion efficiency with values reported for livestock. J. Econ. Entomol. 84, 891-896.

[33] Premalatha M, Abbasi T, Abbasi T and Abbasi SA. (2011). Energy-efficient food production to reduce global warming and ecodegradation, the use of edible insects. Renewable Sust. Energy Rev. 15, 4357-4360.

[34] Jongema Y. (2012). List of Edible Insects of the World. Wageningen University, Wagenin-gen, The Netherlands.

[35] Popa R and Green TR. (2012). Using black soldier fly larvae for processing organic leachates. J. Econ. Entomol. 105, 374-378651.

[36] Katayama N, Ishikawa Y, Takaoki M, Yamashita M, Nakayama S and Kiguchi K. (2008). Entomophagy, a key to space agriculture. Adv. Space Res. 41, 701-705.

[37] Looy H and Wood JR. (2006). Attitudes toward invertebrates, are educational "bug banquets" effective? J. Environ. Educ., Taylor \& Francis Ltd, 37-48.

[38] Mitsuhashi J. (1997). Insects as traditional foods in Japan. Ecol. Food Nutr, 36, 187-199.

[39] Michaelsen KF, Hoppe C, Roos N, Kaestel P, Stougaard M, Lauritzen L, Molgaard C, Girma T and Friis H. (2009). Choice of foods and ingredients for moderately malnourished children 6 months to 5 years of age. Food Nutr. Bull. 30, S343-S404.

[40] Nishimune T, Watanabe Y, Okazaki H and Akai H. (2000). Thiamin is decomposed due to Anaphe spp. entomophagy in seasonal ataxia patients in Nigeria. J.Nutr, 130, 1625-1628.

\section{How to cite this article}

Adewuyi HA, Arogbokun OA, Jaiyeola TO, Ajiboye J, Bawala AE, and Berinyuy EB (2019). The prospects of the use of insects as an alternative source of proteins and medicine for human. GSC Biological and Pharmaceutical Sciences, 9(1), 39-45. 